\title{
Molecular identification and phylogenetic analysis of Trypanosoma evansi in dromedaries (Camelus dromedarius) from Iran
}

\author{
Somayeh Bahrami ${ }^{1 *}$, Ali R. Alborzi ${ }^{1}$, Saeid Rahimi Esfahsalari ${ }^{2}$, and Zahra Ziafati ${ }^{3}$ \\ ${ }^{1}$ Department of Parasitology, Faculty of Veterinary Medicine, Shahid Chamran University of Ahvaz, Golestan \\ Boulevard, Ahvaz, Khuzestan Province, Iran \\ ${ }^{2}$ Department of Food Hygiene, Faculty of Veterinary Medicine, Shahid Chamran University of Ahvaz, Golestan \\ Boulevard, Ahvaz, Khuzestan Province, Iran \\ ${ }^{3}$ Department of Microbiology and Immunology, Faculty of Veterinary Medicine, University of Tehran, Azadi \\ Av.Tehran, Tehran Province, Iran
}

BAHRAMI, S., A. R. ALBORZI, S. RAHIMI ESFAHSALARI, Z. ZIAFATI: Molecular identification and phylogenetic analysis of Trypanosoma evansi in dromedaries (Camelus dromedarius) from Iran. Vet. arhiv 91, 297-305, 2021.

\section{ABSTRACT}

Surra is of great concern to countries in the world such as Iran, which have a considerable camel population. The present study was aimed at determining the prevalence of Trypanosoma evansi in the camels of Iran. A total of 167 blood samples from farmed camels were examined for the presence of $T$. evansi infection using parasitological and molecular methods. Blood smear examination revealed $10(6 \%)$ positive samples, while the PCR method $14(8.4 \%)$ found positive samples. Age, sex, and region were not determined as risk factors for T. evansi infection in this study. The phylogenetic tree inferred from VSG gene sequences of $T$. evansi clearly separated the sequences of this study into two clades, A and B, which reflects the intrasequence heterogeneity among Iranian isolates. The phylogenetic tree showed that Iranian T. evansi strains are members of the T. brucei clade.

Key words: Trypanosoma evansi; camel; Iran; phylogenetic tree

\section{Introduction}

Trypanosoma evansi, the causative agent of cameline trypanosomosis ("Surra"), is the most widespread pathogenic Trypanosoma in the world. It is pathogenic for camels, horses, cats, dogs, Asian elephants (Elephant maximus), pigs and small ruminants (DESQUESNES et al., 2013). Cattle are not very susceptible, except in South East Asia where cerebral signs have been described, but water buffalo (Bubalus bubalis) in South-East Asia frequently suffer from the acute disease that results in a high level of mortality (REID 2002). The virulence of $T$. evansi is particularly pronounced among camels, equines, and dogs that are victims of both acute and chronic diseases, depending on the strain of parasite and the region (HOLLAND et al., 2003). Several hematophagous flies can transmit $T$. evansi mechanically, but the most important are horseflies (Tabanus spp.), followed

\footnotetext{
*Corresponding author:

Somayeh Bahrami, 'Department of Parasitology, Faculty of Veterinary Medicine, Shahid Chamran University of Ahvaz, Golestan Boulevard, Ahvaz, Khuzestan Province, 61357-43311, Iran, E-mail: bahrami.somayeh@gmail.com
} 
by the stable fly (Stomoxys spp.) (LUCKINS 1988). Transmission is enhanced when horses or camels congregate or are closely herded and when they have high numbers of parasites in their blood (RADOSTITIS et al., 2000). In South America, the common vampire bat (Desmodus rotundus) also transmits the infection mechanically through its saliva and high parasitemia may develop which may kill the bat. Recovered bats serve as reservoirs (DESQUESNES et al., 2013). Carnivores can also be infected after ingesting infected meat (RAINA et al., 1985). Parasite multiplication in the blood and body fluids causes inflammatory changes and anemia. The parasite can frequently be found extravascularly in tissues including the central nervous system where it is less exposed to chemotherapeutic agents (TAGER-KAGAN et al., 1989). The first sign of infection by any strain of Trypanosoma is the swelling of the skin ("chancre") where the parasites are multiplying (MAUDLIN et al., 2004). The main clinical findings in $T$. evansi infections are intermittent fever, progressive anemia, lower body part edema, dullness, listlessness, loss of body condition despite a good appetite, nasal and ocular discharge, and terminal nervous signs including paraplegia, paralysis, delirium, and convulsion. Surra is invariably fatal in camels and horses, where death can occur within a few days or a few months, but camels may exhibit chronic signs for years. These signs include a reduction in milk production and capacity for work, and a high abortion rate in pregnant females (LUCKINS, 1988). Surra is of great concern to countries in the world such as Iran, which has a considerable camel population, estimated at nearly 150,000 head. This is $0.56 \%$ of the world camel population and $3.8 \%$ of the Asian camel population (FAO, 2011). In Iran, camels (Camelus dromedarius) are important and popular multipurpose local animals and despite their general reputation for hardiness and resilience, they are vulnerable to many infections (WERNERY et al., 2004) and parasitic agents (BAHRAMI et al., 2016; 2017). The parasitic diseases of camels, particularly those caused by protozoans, have not received adequate attention.

Since the existence of reservoir animals in the vicinity of susceptible camels makes transmission by biting flies possible, identification of infected animals is necessary. Several methods have been developed for detection of T. evansi infection, but polymerase chain reaction (PCR) and DNA sequence analyses have been widely applied to determine the phylogenetic relationships and the interspecific and intraspecific genetic variations of the parasite (AMER et al., 2011). The present study was devoted to the molecular identification of T. evansi derived from naturally infected camels in Iran. The molecular analyses described in this study were based on PCR amplification and sequence analysis of the VSG gene to infer the phylogenetic position of Iranian T. evansi among the Trypanosoma spp.

\section{Materials and methods}

Study area, animals and sample collection. From September 2017 to May 2018, a total of 167 farmed camels were randomly selected from the five geographical regions of Iran with the highest population of camel herds. Ninety samples were collected in Yazd (53.9\%), 26 samples in Zabol (15.6\%), 24 samples in Kerman (14.4\%), 13 samples in Bandar Abbas (7.8\%) and 14 samples in Hoveyze, Khuzestan (8.4\%). The locations of sampling are shown in Fig. 1. Anamnestic data (age, sex, medical history, tick infestation, and clinical signs) were obtained for each animal examined using a bilingual questionnaire. The age of the camels ranged from five months to 30 years (48.5\% were 1 to 4 years old and $51.5 \%$ were older than 4 years old). There were 70 (42\%) females and 97 (58\%) males. Coughing, locomotion problems, and skin lesions were generally mentioned by the owners. All the animals were healthy, and no clinical signs were seen. The blood samples were collected from the jugular vein into sterile vacutainer tubes containing EDTA and kept in $-20{ }^{\circ} \mathrm{C}$ until DNA extraction.

Parasitological examination. Thin blood smears were prepared, fixed with absolute methanol (1 min), stained with $10 \%$ Giemsa solution (30 min) and examined under 1000x magnification (oil immersion lens) to observe $T$. evansi trypomastigotes. More than 30 microscopic fields per blood smear were examined. 


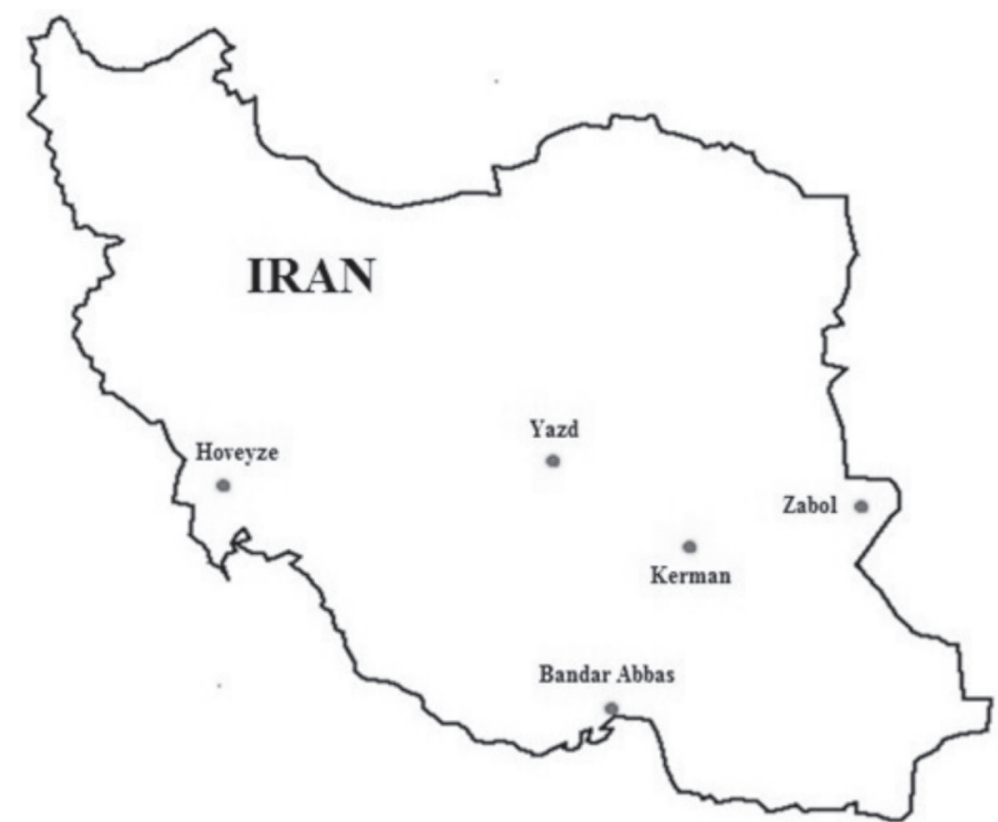

Fig. 1. Map of Iran showing sampling locations: Yazd, Hoveyze, Zabol, Kerman, and Bandar Abbas.

DNA extraction and PCR analysis. DNA was extracted using a genomic DNA purification kit (SinaClon Bioscience, Karaj, 3164819711, Iran). Primers targeting a repetitive region specific for Trypanozoon subgenus pMURTec.F, 5'-TGCAGACGACCTGACGCTACT; pMURTec.R,5'-CTCCTAGAAGCTTCGGTGTCCT were used (WUYTS et al., 1994). PCR reactions included a negative control consisting of the reaction mix and $2 \mu \mathrm{L}$ of DNase/RNase-free water instead of DNA, and a positive control consisting of a DNA sample from a $T$. evansi positive blood sample from a camel with clinical trypanosomosis. All PCRs were performed as a $25 \mu \mathrm{L}$ reaction containing $12.5 \mu \mathrm{L}$ Taq DNA polymerase master mix Red (Amplicon, Odense, Denmark), $1 \mu \mathrm{M}$ primers, and 50 ng DNA templates. The cycles included an initial step at $94{ }^{\circ} \mathrm{C}$ for $4 \mathrm{~min}$, followed by 30 cycles of denaturing at $94{ }^{\circ} \mathrm{C}$ for $30 \mathrm{~s}$, annealing at $60{ }^{\circ} \mathrm{C}$ for $30 \mathrm{~s}$ and extension at $72^{\circ} \mathrm{C}$ for $30 \mathrm{~s}$. PCR elongation was continued at $72{ }^{\circ} \mathrm{C}$ for $5 \mathrm{~min}$. Amplification products were resolved in $1.5 \%$ molecular grade agarose gel (Fischer Biotech, Australia) stained with CYBR Safe stain. Approximately $5 \mu \mathrm{L}$ of the PCR product from five camels were subsequently purified using the PCR purification kit (Vivantis, Revongen Corporation Center, 47600 Subang Jaya,
Selangor Darul Ehsan, Malaysia) and sequenced by specific primers and the Big Dye Terminator V.3.1 Cycle Sequencing kit in an ABI 3130 Genetic Analyzer (Applied Biosystems, 850 Lincoln Centre Drive Foster City, CA 94404, USA).

Genetic diversity and phylogenetic tree construction. The nucleotide sequence multiple alignments and quality checking were accomplished using T- coffee and ClustalW. All nucleotide sequences obtained were deposited in the Genbank with the assigned accession numbers. The phylogenetic relationship was examined and constructed using the Molecular Evolutionary Genetic Analysis (MEGA), version 7. On the basis of the Bayesian information criterion, the optimal phylogenetic parameter of choice was the JukesCantor model (JC). Maximum likelihood analyses were done based on the substitution method, and the sequences were subjected to a 1000 replicate bootstrap test. T. cruzi, accession number K02631.1, was used as an outgroup.

Statistical analysis. Fischer Exact and Chisquare tests were used to compare infection rates among different age, sex and location groups. $\mathrm{P}$ values of $<0.05$ were considered statistically significant. 


\section{Results}

Trypomastigote forms of $T$. evansi (6\%) were found in 10/167 prepared blood smears. In 14 samples of these 167 samples examined $(8.4 \%)$ a band of approximately $220 \mathrm{bp}$ was shown on the agarose gel which considered as a positive result of the PCR.

On the basis of the molecular results, 7/70 females (10\%) and 7/97 males (7.21\%) were found to be positive. Therefore, there was no significant difference between the prevalence rate of infection in males and females (CI, 0.23-2.09). The prevalence of infection in camels under four years old was $11.62 \%$, while a prevalence rate of $4.93 \%$ was detected in camels older than four years old (CI, 0.76-8.42). Thus, based on these results, age was not identified as a risk factor for T. evansi infection in this study $(\mathrm{P}=0.11)$.

There was no significant geographical variation in the prevalence of $T$. evansi infection, ranging from $0 \%$ in Kerman to $14.3 \%$ in Ahvaz (CI, 0.691.06) (Table 1).

Among the 14 positive samples, five were sequenced to verify the positive results. The average size fragment of the gene from the amplified $T$. evansi was $220 \mathrm{bp}$. The amplified gene sequences varied from 204 to $228 \mathrm{bp}$. The consensus gene sequences were blasted in the NCBI Genbank database, and they showed T. evansi VSG gene percentage identity ranging from 95 to 98.38 . The nucleotide sequences of the VSG gene from $T$. evansi were submitted to the NCBI GenBank and assigned the accession numbers MF188845.1 and MK752393 to MK752396. After a few processes of removal and alignment of sequences using the T- coffee molecular software, $200 \mathrm{bp}$ of the partial VSG gene from the 21 sequences of $T$. evansi and $T$. bruce $i$ and one outgroup, T. cruzi were successfully obtained. The overall frequency distributions of nucleotides in the first, second, and third codon positions are as follows: $\mathrm{T}=25.2 \%, 22 \%$, and $16 \% ; \mathrm{C}=20.9 \%, 21.3 \%$, and $30.9 \% ; \mathrm{A}=33.6 \%$, $31.3 \%$, and $24.7 \% ; \mathrm{G}=20.3 \%, 25.6 \%$, and $28.4 \%$, respectively. Analysis of the sequences revealed a mean GC content of $49.2 \%$. The analysis of the homogeneity of the substitution patterns between sequences using the Disparity Index Test (Monte Carlo Test) with 500 replicates, revealed significant differences across the MK752393 and other sequences (MF188845.1: $\mathrm{P}=0.0, \mathrm{MK} 752394: \mathrm{P}$ $=0.0$, MK752395: $\mathrm{P}=0.0$ and MK752396: $\mathrm{P}=$ $0.004)$. The partial VSG gene sequence variation within the $T$. evansi strains detected in this study was $0.00-0.10 \%$ (Table 2 ).

Table 1. Prevalence of T. evansi in camels from Iran and related factors

\begin{tabular}{|c|c|c|c|c|c|c|}
\hline Factor & $\begin{array}{c}\text { No. of } \\
\text { examined }\end{array}$ & $\begin{array}{c}\text { No. of } \\
\text { positive }\end{array}$ & $\%$ & $\mathrm{P}$ - value & OR & CI95\% \\
\hline Prevalence & 167 & 14 & 8.38 & - & - & - \\
\hline \multicolumn{7}{|l|}{ Sex } \\
\hline Female & 70 & 7 & 10 & - & - & - \\
\hline Male & 97 & 7 & 7.21 & 0.52 & 0.7 & $0.23-2.09$ \\
\hline \multicolumn{7}{|l|}{ Age } \\
\hline$>4$ years old & 81 & 4 & 4.93 & - & - & - \\
\hline$\leq 4$ years old & 86 & 10 & 11.62 & 0.11 & 2.53 & $0.76-8.42$ \\
\hline \multicolumn{7}{|l|}{ Locality } \\
\hline Kerman & 24 & 0 & 0 & - & - & - \\
\hline Zabol & 26 & 2 & 7.7 & 0.17 & 1.9 & $0.97-1.21$ \\
\hline $\begin{array}{l}\text { Yazd } \\
\text { Ahvaz } \\
\text { Bandar Abbas }\end{array}$ & $\begin{array}{l}90 \\
14 \\
13\end{array}$ & $\begin{array}{l}9 \\
2 \\
1\end{array}$ & $\begin{array}{c}10 \\
14.3 \\
7.7\end{array}$ & $\begin{array}{l}0.11 \\
0.13 \\
0.16\end{array}$ & $\begin{array}{l}2.6 \\
3.6 \\
1.9\end{array}$ & $\begin{array}{l}1.04-1.19 \\
0.69-1.06 \\
0.79-1.08\end{array}$ \\
\hline
\end{tabular}




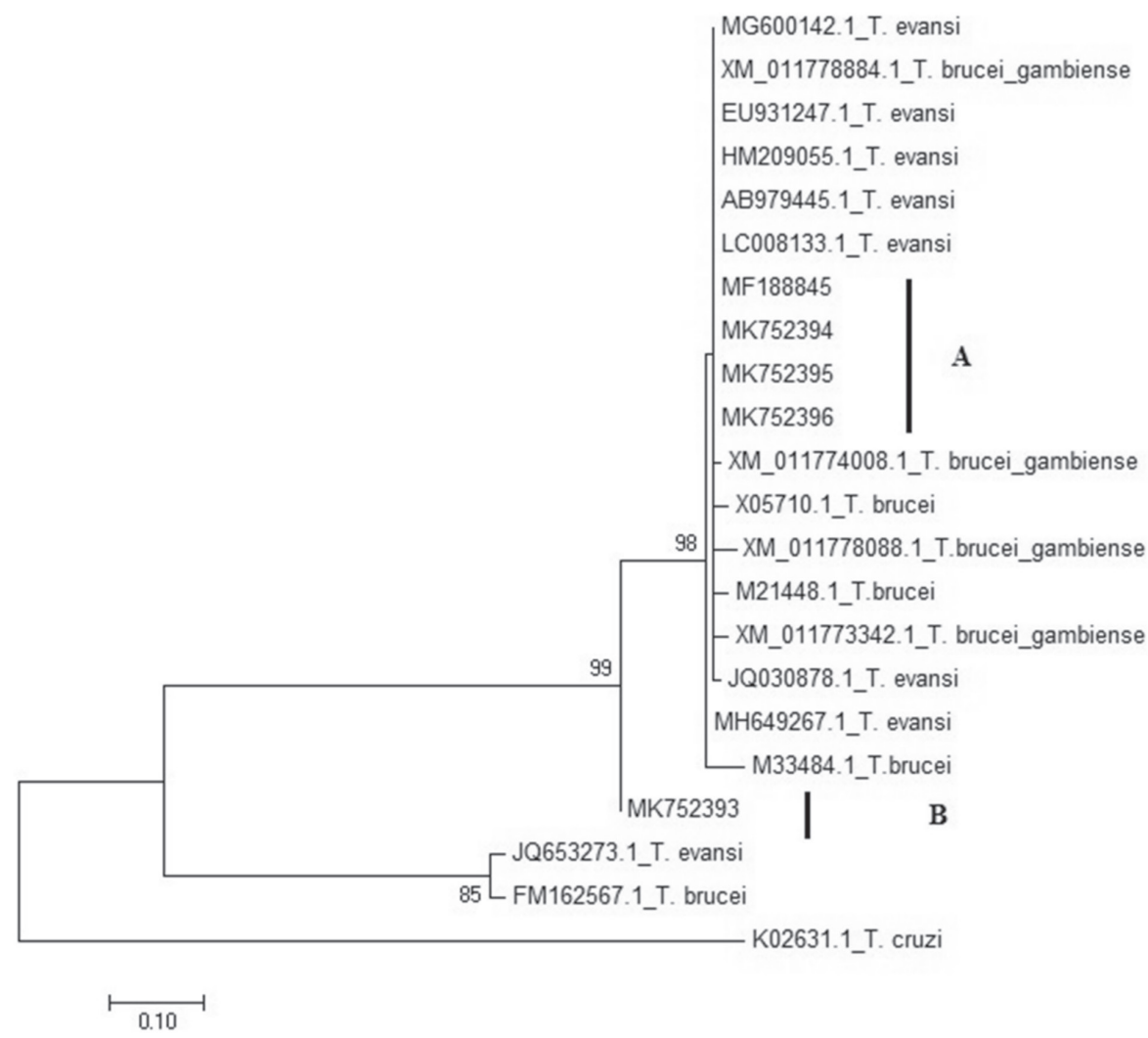

Table 2. Estimates of evolutionary divergence between Sequences. The number of base substitutions per site from between sequences is shown. Analyses were conducted using the Jukes-Cantor model.

The phylogenetic tree inferred from the VSG gene sequences of $T$. evansi clearly separated the sequences into two clades, A and B clades. All the samples were placed in clade A except the MK752393 sequence from Bandar Abbas. Furthermore, the phylogenetic tree showed that Iranian isolates of $T$. evansi grouped with $T$. brucei subspecies. T. cruzi used as an outgroup was clearly separated to the periphery of the phylogram.

\section{Discussion}

In the present study, ten camels out of $167(6 \%)$, showed T. evansi positive blood smears with lowgrade parasitemia, while the overall prevalence rate of $T$. evansi infection by PCR was found to be $8.4 \%$. The blood smear technique requires a small sample volume, a skilled diagnostician, and continues to be a convenient and useful diagnostic method for direct observation of hemoflagellate parasites. It is still a confirmative tool and one of the best techniques used for studying parasites, but is less sensitive than other techniques, such as molecular methods. Compared with microscopy of blood smears, the PCR method had higher sensitivity and is recommended for use in the diagnosis of trypanosomosis. Several molecular tests for parasite detection have been developed in the last decade. Their specificity and sensitivity have gradually increased, and parasites that were previously difficult to diagnose using conventional techniques have begun to be identified by molecular techniques. Thus, early detection and early treatment can greatly reduce the negative impact on a population. The prevalence of $T$. evansi recorded during this study was comparable with earlier reports from Iran (MOGHADDAR and DIANTPOUR, 2009; SAZMAND et al., 2011). However, previous studies have reported a higher prevalence of $T$. evansi. It should be mentioned that in the present study there were no clinical signs in the sampled animals. MIRSHEKAR et al. (2017) found that 97 out of 369 examined camels $(25.75 \%)$ 
with clinical signs $(15.8 \%, 58 / 369)$ were be infected with $T$. evansi in the southeast of Iran.

Some studies indicate that the parasitemia can be higher in the dry season than in the wet season, possibly due to the increased activity of biting flies (ELAMIN et al., 1998). The study by SALIM et al., (2011), which was carried during the dry season (late September to November), supports the idea that the congregation of camel herds at the scarce water holes brings the animals into close proximity and facilitates the efficient transmission of the parasite by flies. In this study, we expected a higher T. evansi prevalence. However, the low prevalence is maybe related to the sampling season (September to May) and could be linked to the low fly densities in these periods.

In the present study, the gender of the tested camels showed no significant difference between the infected and non-infected animals. However, some studies did find a correlation between gender and positivity, where they indicate that gender is a risk factor for trypanosomosis in their area (BARGHASH et al., 2014; SOBHY et al., 2017). They considered successive pregnancies and lactation stress as the main factors of the significant higher infection rates in females.

In this survey the age factor was not considered as a risk factor because there was no significant difference within the age category. The age of the infected camels in the present study ranged between five months and 30 years, which suggests that differentages could have been exposed to the parasite. This finding is different from the data published by other authors who concluded that older camels showed a higher prevalence of trypanosomosis (ATARHOUCH et al., 2003; GUTIERREZ et al., 2000; MOGHADDAR and DIANTPOUR, 2009; TADESSE et al., 2012). This could be explained in part by different age categorization. In Iran, camel rearing in most parts of the country generally takes place in villages, in desert areas with hot summers, and rarely in mountainous and plain areas. In some studies, significant differences in positivity between geographical areas were attributable to differences in the management of the animals, including their nutrition, host activity, and differing climates (SALIM et al., 2011). Since all the farms participating in the present study had almost the same management and all the localities had the same climates, there were no significant differences in prevalence among the different regions.

Molecular analysis is essential for phylogenetic analyses and determination of the taxonomic identities of trypanosomosis (STEVENS et al., 2001). In this study, the BLAST comparison of the partial sequences of VSG gene revealed 98.4\% homology with the sequence from the $T$. evansi strain collected from a horse (LC008133.1) and cattle (AB979445) in Punjab, India, 99.8\% homology with $T$. evansi from cattle in Thailand (AY912277), and 97.8\% homology with isolates from dogs in Thrissur, Kerala (MG600142). Phylogenetic analyses of $T$. evansi revealed neither host nor geographic specificity. In this context, the introduction of infected animals is a risk factor for the spread of the disease. POURJAFAR et al. (2013) showed that $T$. evansi is probably related to the capacity for rapid adaptation to different host species and environments. The phylogenetic trees based on the VSG gene sequence analyzed in the present study were helpful for unravelling the phylogenies and relatedness of the Iranian isolates. The Iranian isolates were clustered with those of $T$. evansi retrieved from Genbank. Maximum parsimony analyses showed that the MK752393 isolates are distinctly separated from other sequences (Fig. 2). This pattern unexpectedly reflects the intrasequence heterogeneity among Iranian isolates, despite its being very subtle (eleven single nucleotide polymorphism sites within $200 \mathrm{bp}$ ). Furthermore, on the basis of the phylogenetic tree in this study, it seems that the gene sequence revealed the extensive similarity of T. evansi and T. brucei, and supports the claim of CARNES et al., (2015) that T. evansi should be classified as a subspecies of T. brucei. In the same study, phylogenetic analysis demonstrated that $T$. evansi, and the closely related horse parasite $T$. equiperdum, evolved more than once from T. brucei. Authors also demonstrated extensive similarity to T. brucei, including the maintenance of numerous genes that $T$. evansi no longer requires. Therefore, despite the significant functional and pathological differences between T. evansi and T. brucei, their analysis supported the opinion that T. evansi is not an independent species. 


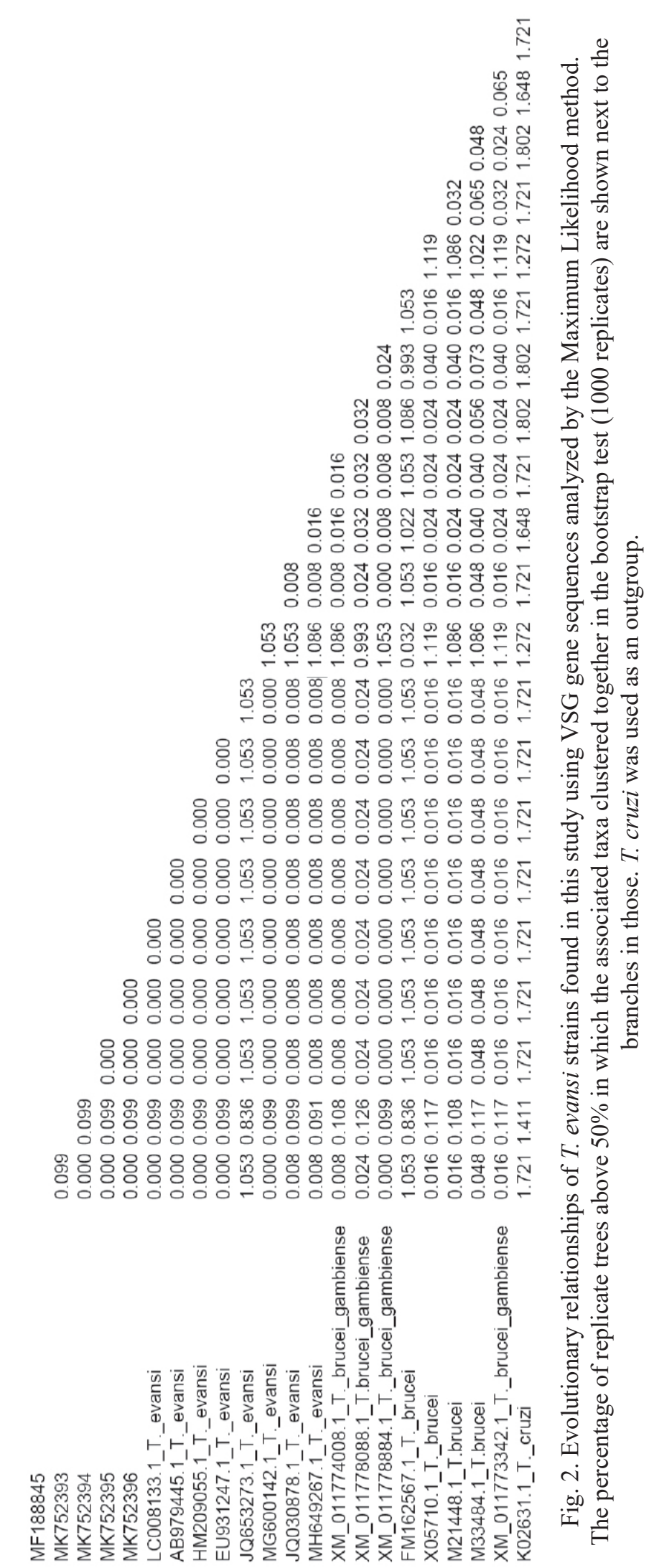




\section{Conclusions}

In conclusion, the genetic diversity of T. evansi in Iranian dromedary camels was shown in our study. The results may be used as preliminary data for studying genetic diversity and the dynamics of T. evansi.

\section{Acknowledgment}

This study was supported by a research grant provided by the Shahid Chamran University of Ahvaz.

\section{References}

AMER, S., O. RYU, C. TADA, Y. FUKUDA, N. INOUE, Y. NAKAI (2011): Molecular identification and phylogenetic analysis of Trypanosoma evansi from dromedary camels (Camelus dromedarius) in Egypt, a pilot study. Acta. Trop. 117, 39-46.

DOI: 10.1016/j. actatropica.2010.09.010

ATARHOUCH, T., M., RAMI, M., BENDAHMAN, A. DAKKAK (2003): Camel trypanosomosis in Morocco 1: results of a first epidemiological survey. Vet. Parasitol. 111, 277-286.

DOI: 10.1016/s0304-4017(02)00382-5

BAHRAMI, S., M. R. TABANDEH, A. R. GANJALI TAFRESHI (2017): Prevalence and molecular identification of piroplasmids in Iranian dromedaries (Camelus dromedarius). J. Zoo Wildl. Med. 48, 1026-1030.

DOI: $10.1638 / 2016-0233.1$

BAHRAMI, S., M. R. TABANDEH, A. NIKBIN, A. R. ALBORZI, A. R. GHADRDAN (2016): Prevalence and phylogenetic analysis of Theileria equi in Iranian dromedaries. Arch. Razi Inst. 71, 161-175.

BARGHASH, S. M., T. R. EL-NAGA, E. A. EL-SHERBENY, A. M. DARWISH (2014): Prevalence of Trypanosoma evansi in Maghrabi camels (Camelus dromedarius) in Northern-West Coast, Egypt using molecular and parasitological methods. Acta Parasitol. Glob. 5, 125-132. DOI: $10.4172 / 2155-9597.1000258$

CARNES, J., A. ANUPAMA, O. BALMER, A. JACKSON, M. LEWIS, R. BROWN, I. CESTARI, M. DESQUESNES, C. GENDRIN, C. HERTZ-FOWLER, H. IMAMURA, A. IVENS, L. KOŘENÝ, D. H. LAI, A. MACLEOD, S. M. MCDERMOTT, C. MERRITT, S. MONNERAT, W. MOON, P. MYLER, I. PHAN, G. RAMASAMY, D. SIVAM, Z. R. LUN, J. LUKEŠ, K. STUART, A. SCHNAUFER (2015): Genome and phylogenetic analyses of Trypanosoma evansi reveal extensive similarity to $\mathrm{T}$. brucei and multiple independent origins for dyskinetoplasty. PLoS Negl. Trop. Dis. 9, e3404.

DOI: 10.1371/journal.pntd.0003404

DESQUESNES, M., P. HOLZMULLER, D. H. LAI, A. DARGANTES, Z. R. LUN, S. JITTAPLAPONG (2013):
Trypanosoma evansi and Surra: A Review and perspectives on origin, history, distribution, taxonomy, morphology, hosts, and pathogenic effects. Biomed. Res. Int. 2013, 194176.

DOI: $10.1155 / 2013 / 194176$

ELAMIN, E. A., M. O. EL BASHIR, E. M. SAEED (1998): Prevalence and infection pattern of Trypanosoma evansi in camels in mid-eastern Sudan. Trop. Anim. Health Prod. 30, 107-114.

FOOD AND AGRICULTURE ORGANIZATION OF THE UNITED NATIONS, ROME. (2011): Available at http:// faostat. fao. org [verified 2 Octuber 2013].

GUTIERREZ, C., M. JUSTE, J. CORBERA, E. MAGNUS, D. VERLOO, J. MONTOYA (2000): Camel trypanosomosis in the Canary Islands: assessment of seroprevalence and infection rates using the card agglutination test (CATT/T. evansi) and parasite detection tests. Vet. Parasitol. 90, 155159.

DOI: $10.1016 / \mathrm{s} 0304-4017(00) 00225-9$

HOLLAND, W. G., T. T. DO, N. T. HUONG, N. T. DUNG, N. G. THANH, J. VERCRUYSSE, B. M. GODDEERIS (2003): The effect of Trypanosoma evansi infection on pig performance and vaccination against classical swine fever. Vet. Parasitol. 111, 115-123.

DOI: 10.1016/s0304-4017(02)00363-1

LUCKINS, A. G. (1988): Trypanosoma evansi in Asia. Parasitol. Today 4, 137-42.

MAUDLIN, I., P. H. HOLMES, M. A. MILES (2004): The Trypanosomiasis. CABI Publishing CAB International, Oxfordshire, UK, pp. 25-30, 283-331.

MIRSHEKAR, F., M. YAKHCHALI, F. SHARIATI-SHARIFI (2017): Trypanosoma evansi infection and major risk factors for Iranian one-humped camels (Camelus dromedaries). J. Parasit. Dis. 41, 854-858. DOI: $10.1007 / \mathrm{s} 12639-017-0905-7$

MOGHADDAR, N., V. DIANTPOUR (2009): Distribution pattern of Trypanosoma evansi in camels (Camelus dromedarius) in Iran. J. Camel Pract. Res. 16, 73-75.

POURJAFAR, M., K. BADIEI, H. SHARIFIYAZDI, A. CHALMEH, M. NAGHIB, M. BABAZADEH, A. MOOTABI ALAVI, N. HOSSEINI JOSHANI-ZADEH (2013): Genetic characterization and phylogenetic analysis of Trypanosoma evansi in Iranian dromedary camels. Parasitol. Res. 112, 899-903.

DOI: $10.1007 / \mathrm{s} 00436-012-3121-5$

RADOSTITIS, O. M., C. C. GAY, D. C. BLOOD, K. W. K. HINCHCLIFF, C. GAY (2000): Veterinary Medicine: A Textbook of the Diseases of Cattle, Sheep, Pigs, Goats and Horses. $9^{\text {th }}$ ed., WB Saunders, London, ISBN: 9780702026041, p. 1877.

RAINA, A. K., R. KUMAR, V. S. RAJORA SRIDHAR, R. P. SINGH (1985): Oral transmission of Trypanosoma evansi infection in dogs and mice. Vet. Parasitol. 18, 67-69.

DOI: 10.1016/0304-4017(85)90009-3 
REID, S. A. (2002): Trypanosoma evansi control and containment in Australasia. Trends Parasitol. 18, 219-224. DOI: $10.1016 / \mathrm{s} 1471-4922(02) 02250-\mathrm{x}$

SALIM, B., M. A. BAKHEIT, J. KAMAU, I. NAKAMURA, C. SUGIMOTO (2011): Molecular epidemiology of camel trypanosomiasis based on ITS1 rDNA and RoTat 1. 2 VSG gene in the Sudan. Parasit. Vectors. 4, 31-36.

DOI: $10.1186 / 1756-3305-4-31$

SAZMAND, A.,A. RASOOLI, M. NOURI, H.HAMIDINEJAT, S. HEKMATIMOGHADDAM (2011): Serobiochemical alterations in subclinically affected dromedary camels with Trypanosoma evansi in Iran. Pakistan Vet. J. 31, 223-226.

SOBHY, H. M., S. M. BARGHASH, T. S. BEHOUR, E. A. RAZIN (2017): Seasonal fluctuation of trypanosomiasis in camels in North-West Egypt and effect of age, sex, location, health status and vector abundance on the prevalence. Beni-Seuf Univ. J. Appl. Sci. 6, 64-68.

DOI: 10.1016/j. bjbas. 2017. 01. 003

STEVENS, J. R., H. A. NOYES, C. J. SCHOFIELD, W. GIBSON (2001): The molecular evolution of Trypanosomatidae. Adv. Parasitol. 48, 1-56.
TADESSE, A., A. OMAR, K. ARAGAW, B. MEKBIB, D. SHEFERAW (2012): A study on camel trypanosomosis in Jijiga zone, Eastern Ethiopia. J. Vet. Adv. 2, 216-219.

TAGER-KAGAN, P., J. ITARD, M. CLAIR (1989): Testing of the efficacy of Cymelarsan ND on Trypanosoma evansi in dromedary. Rev. Elev. Med. Vet. Pays. Trop. 42, 55-61 (in French).

DOI: $10.19182 /$ remvt.9078

WERNERY, U., A. UL-HAQ, M. JOSEPH, J. KINNE (2004): Tetanus in a camel (Camelus dromedarius): a case report. Trop. Anim. Health Prod. 36, 217-224.

DOI: 10.1023/b:trop.0000016835.02928.28

WUYTS, N., N. CHOKESAJJAWATEE, S. PANYIM (1994): A simplified and highly sensitive detection of Trypanosoma evansi by DNA amplification. S. E. Asian J. Trop. Med. Publ. Health 25, 266-271.

Received: 20 May 2020

Accepted: 13 October 2020

\section{BAHRAMI, S., A. R. ALBORZI, S. RAHIMI ESFAHSALARI, Z. ZIAFATI: Molekularna identifikacija i filogenetska analiza Trypanosoma evansi u jednogrbih deva (Camelus dromedarius) iz Irana. Vet. arhiv 91, 297- $305,2021$.}

\section{SAŽETAK}

Sura je bolest od posebne važnosti u zemljama kao što je Iran, koje imaju veliku populaciju deva. Cilj ovoga istraživanja bio je odrediti prevalenciju Trypanosoma evansi u deva u Iranu. Ukupno 167 uzoraka krvi farmski držanih deva istraživano je na prisutnost invazije s T. evansi primjenom parazitoloških i molekularnih metoda. Istraživanje krvnog razmaza pokazalo je 10 (6 \%) pozitivnih uzoraka, dok je PCR pokazao $14(8,4 \%)$ pozitivnih uzoraka. U ovom istraživanju dob, spol i područje uzgoja nisu određivani kao rizični čimbenici za invaziju s T. evansi. Filogenetsko stablo izvedeno iz sekvencija VSG gena T. evansi jasno je razdvojilo sekvencije u dvije klade, A i B, i odražava unutarsekvencijsku heterogenost među iranskim izolatima. Filogenetsko stablo pokazalo je da su iranski sojevi $T$. evansi članovi klade T. brucei.

Ključne riječi: Trypanosoma evansi; deva; Iran; filogenetsko stablo 
